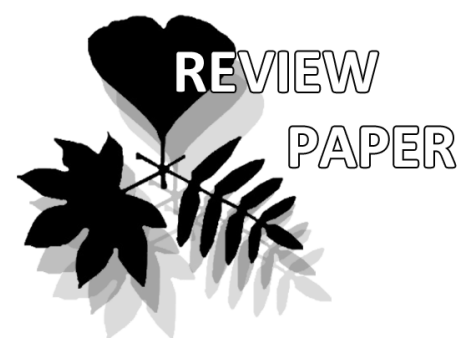

\title{
Phylogenesis, Origin and Kinship of the Charophytic Algae
}

\author{
Galina M. Palamar-Mordvintseva ${ }^{1}$, Petro M. Tsarenko ${ }^{1}$, \\ Sophia Barinova ${ }^{2}$
}

Galina M. Palamar-Mordvintseva ${ }^{1}$ e-mail: ptsar@ukr.net.

Petro M. Tsarenko ${ }^{1 *}$ e-mail: ptsar@ukr.net

Sophia Barinova ${ }^{2}$

e-mail: barinova@research.haifa.ac.il

${ }^{1}$ N.G. Kholodny Institute of Botany, NAS of Ukraine, Kiev, Ukraine

${ }^{2}$ Institute of Evolution,

University of Haifa, Haifa, Israel

* corresponding author

Manuscript received: 04.08.2015 Review completed: 02.10.2015

Accepted for publication: 10.10 .2015

Published online: 24.10.2015

\begin{abstract}
A B S T R A C T
We analyzed phylogenetic reconstructions of charophytes (streptophyte) algae and assessed the importance of new phylogenetic hypotheses on some aspects of the evolution of plants. We give attention to the progress made in modern molecular biology study, and the occurrence of biological features and life cycles of organisms and multicellular gravitropism based on the results of molecular physiology and genome evolution. We analyzed generalized information on the significance and place of Charophyta in the development of plants, how these plants were settled on land and their further development. We represent ideas about the modern interpretation of ancestral forms and consanguinity of this group of algae with other taxa of plants. We used a phylogenetic approach in analysis of formation and methods of cell division, with a deeper concept of complexity of the process of plant organization (the transition from unicellular to multicellular). We assessed evolutionary significance of the gravitropism phenomenon and some features of molecular and physiological changes in plant organisms during the change of environments and their outlet to the earth. Summarized and analyzed the changes in the modern paradigm in respect of group of streptophytes algae which can be assessed as a basis of other plants and close related to Zygnematales-line group of algae on the phylogenetic tree.
\end{abstract}

K e y w o r d s : Charophytes, phylogenies, evolution, origin, phylogenetic relationships

\section{P E 3 Ю M E}

Паламарь-Мордвинцева Г.М., Царенко П.М., Баринова С.С. Фимогенез, происхожАение и родственные связи харофитовых водорослей. Представлены материалы анализа филогенетических реконструкций харофитовых водорослей, а также освещена значимость новых филогенетических гипотез о некоторых аспектах эволюции растений, с учетом современного прогресса в их молекулярно-биологическом изучении, раскрытии особенностей биологии жизненных циклов и развития организмов, возникновении многоклеточности и гравитропизма, с учетом результатов молекулярной физиологии и эволюции генома. Обобщены данные о формировании преАстав ений о значимости харофитов в становлении мира растений, заселении ими суши и дальнейшего их развития. ОбсужАается современная трактовка анцестральных форм и родственных связях этой группы водорослей с Аругими таксонами растительного мира. С использованием филогенетического подхода показаны особенности формирования и деления клетки, а также особенности процесса усложнения растительной организации (переход от одноклеточности к многоклеточности) и молекулярно-физиологических изменений растительных организмов в период смены среды обитания и выхода их на сушу. Обобщены и проанализированы материалы относительно смены или модификации современной парадигмы о близкородственной группе стрептофитовых водорослей к базису Аругих растений и родственной сестринской Аинии Zygnematales на филогенетическом Ареве.

К
Charophyte algae is a monophyletic group of streptophyte lines in the evolution of plants (Viridiplantae), which dissociated itself from chlorophyte lines more than 450 million years ago. This taxonomic group now unites unicellular and multicellular organisms (monocytes and coenocytes) with different morphological structure of thalluses, are characterized by many morphological and cytological features similar to other representatives of Streptophyta, growing in diverse environment such as water and soil.
Classic morphological and taxonomic ideas of direct family connections of charophytes algae (Charales) with cryptogams or the consideration of the group as direct ancestors of "higher plants" have not been confirmed by molecular biological research. Also, there is no consensus about how these related groups of plants are phylogenetically related to other plants. In particular, if Mesostigma viride Lauterborn is the ancestral form of Viridiplantae (Bhattacharia \& Medlin 1998, Lemieux et al. 2000, 2007, Rodriguez-Ezpeleta et 
al. 2007) on the base of genomic and chloroplast-nuclear mitochondrial composition, or considered as complex of species M. viride and Chlorokybus atmophyticus Geitler (Lemieux et al. 2007), then the sisterly phylogenetic lines in this case is deduced from different taxonomic groups of the Charophytes - Zygnematales / Zygnematophyceae (Turmel et al. 2006, Gontcharov 2008, 2009, Wodniok et al. 2011, Timme et al. 2012, Zong et al. 2013, Ruhfel et al. 2014, Wickett et al. 2014), Coleochaetales (Turmel, Gagnon et al. 2009, Turmel et al. 2009) or Coleochaetales with Zygnematales (Finet et al. 2010, Laurin-Lemay et al. 2012).

The aim of this work is to analyze and generalize information about the modern progress of the Charophyte algae phylogenetic reconstructions, coverage of the significance of new phylogenetic hypotheses on some key aspects of the evolution of plants with special attention to molecular biological research, the disclosure of life cycle features, the causes of the emergence of multicellularity and gravitropism, as well as to analyze the results and ideas of molecular physiology in evolution of the charophytes genomes. The tasks are associated with the preparation of Charophyte algal flora of Ukraine and analyses of various aspects that affect this group of aquatic plants. Location and value of the Charophyte algae in the organic world have been discussed earlier (Palamar-Mordvintseva \& Tsarenko 2009).

\section{Phylogenesis of the Charophytes}

Reconstruction of the phylogeny of organisms was the main aim of biology after the publication of Darwin's theory of the evolution of organisms (Darwin 1859). The emergence of land plants (Embryophyte) was one of the greatest events in the history of living things, which caused an irreversible evolutionary process in the formation of life on Earth. Setting cladistics principles (Henning 1966) and scientific achievements of 1960-1970 years (Pickett-Heaps 1967, 1975, Picket-Heaps \& Marchant 1972, Marchant \& PickettHeaps 1973), which outlined precise conceptual frameworks for the disclosure of relationships between organisms and formal separation of charophytic algae in the modern sense of the group's volume and its diagnostic features (Mattox \& Stewart 1984), based on information about the features of cell division and the ultrastructure of the flagellated apparatus, made a significant contribution to taxonomy, arguing first clear phylogenetic frame for many groups of organisms. Significant improvement in phylogenetic research was the reason for historical study of the mechanisms and processes in most major evolutionary events using the formulation of hypotheses in the evolutionary patterns of organisms, which led to the creation of a new System Evolution Theory (SET) by Valentin Krassilov (2014).

While early morphological cladistics studies made a great contribution in taxonomy, erroneous interpretations of features and the underestimation of homoplasy led to the formulation of some false hypotheses. In the early stage of molecular studies single genes were used, often without extensive taxa, resulting in questionable phylogenetic hypotheses. However, false speculation ended after attracting automatic processing technology sequences of RNA and DNA, which has enabled a more systematic use of genes, often from one to several cellular structures, or multiple groups of organisms. As a result, the significant evidences, which support phylogenetic developments, were obtained (Delsue et al. 2003, Qiu 2008, Becker \& Marin 2009, Gontcharov 2009, Finet et al. 2010, Zong et al. 2013). In addition, the use of modern, highly developed sequencing technology and increasing the number of investigated taxa have improved our understanding in problem solving of phylogenetic studies and enriched the base for the complicated phylogenetic reconstructions (Brinkmann \& Phillipe 2008). In the traditional taxonomy we can use all sources of newest phylogenetic data that give us much more information and coverage of diverse approaches to decrypt historical models of evolution.

It has clearly been established that 'green plants', Viridiplantae (Levis \& McCourt 2004, Qiu 2008, Becker \& Marin 2009, Gontcharov 2008, 2009, Finet et al. 2010), unite all the 'green' algae with land plants (Embryophyte). They are the monophyletic group of organisms with an extraordinary variety of morphology, cell structure, life history, reproduction, and biochemistry. 'Green plants' has been divided early enough into two evolutionary phyla (lines): green algae (Chlorophyta) and charophytic algae (Charophyta) with embryophyte (Streptophyta). This separation happened about 725-1,200 million years ago (Hedges et al. 2004, Yoon et al. 2004, Zimmer et al. 2007). In comparison with the chlorophyte line of evolution, which accommodates most types of traditional division Chlorophyta (100 genera and more then 10000 species), the Charophyte (Streptophyte) line contains relatively few existing green charophytic algae (about 65 genera and several thousand species), which, together with almost half a million species of land plants (Embryophyte) compose the Streptophyta division (sensu Bremer et al. 1987), or the Charophyta (sensu Levis \& McCourt 2004).

The descendants of the Charophyte algae occupied land habitats about 450-470 million years ago that became an extraordinary event in the evolution of life on Earth (Graham 1993, Kenrick \& Crane 1997, Bateman et al. 1998).

Within the Charophyte algae six distinct morphological groups were allocated: 1) flagella (Mesostigmatales), 2) sarcinoid (Chlorokybales), 3) filamentous (unbranched) (Klebsormidiales), 4) conjugates (Zygnematales - sexual reproduction in the form of conjugation, the total absence of motile cells) and two morphologically complex groups: Coleochaetales and Charales, which are characterized by multicellular (with plasmodesms) or parenchyma-shaped tissue thalluses, with patulous branches, apical growth and oogamic sexual reproduction. Also, it was established that Mesostigma viride sets one clade along with Chlorokybus atmophyticus, forming an early divergent ancestral line of charophytic (Streptophyte) algae (Lemieux et al. 2007, Rodriguez-Ezpeleta et al. 2007, Qiu 2008, Becker \& Marin 2009). However, there are still important issues related to the group of the Charophyte algae that act as a sister to Embryophyte.

In most illustrated constructions of the evolution of the Charophyte algae and land plants Charophytes often act as sister group of land plants (Qiu 2008, Becker \& Marin 2009). Previously, through a unique and relatively complex 
thallome and peculiarities of the reproductive organs, charophytic algae were considered as a potential group of algae tightly linked to land plants (Boldt \& Wynne 1985). This hypothesis was supported by ultrastructure (McCourt et al. 1996) and molecular phylogenetic data (Fig. 1) (Karol et al. 2001, McCourt et al. 2004).

The phylogenetic tree of the Streptophyte, constructed based on a joint analysis of 4 gene from 3 genomes (nuclear $18 \mathrm{~S}$ rDNA, chloroplast $a t p \mathrm{~B}$ and $r b c \mathrm{~L}$, and mitochondrial nadS), clearly demonstrated that the Charophytes are the sister group of land plants, and their ratio had high bootstrap support. The close relationship of the Charophytes and land plants coincides well with the traditional hypothesis about the direction of evolution of morphological, ultrastructural, and biochemical traits in algae that led to the release of plants on land and to a successful adaptation (McCourt et al. 2004).

However, in some modern phylogenetic studies, Coleochaetales and Zygnematales are also characterized as sister groups of land plants. Ultrastructural studies revealed cell division due to a type of phragmoplast in Zygnematales that brought them together with charophytic (Charales) and Coleochaetes (Coleochaetales) algae, as well as with terrestrial plants (Mattox \& Stewart 1974, Pickett-Heaps 1975). The following biochemical and molecular studies have found that Zygnematophyceae is one of the advanced groups of Streptophyte algae, although no one of the obtained topologies has been supported statistically. Nevertheless, phy- logenetic analysis of nucleotide sequences of nuclear ribosomal 18S rDNA and chloroplast protein-coding genes $r b c \mathrm{~L}$ questioned the sisterhood of the Charophytes and terrestrial plants (Turmel et al. 2002). Analyses of 76 chloroplast genes unexpectedly showed that the conjugates are the nursing group of terrestrial plants (Gontcharov 2008, 2009; Fig. 2).

Zygnematophyceae location on the phylogenetic tree was solidly confirmed by high bootstrap values and genes order in the chloroplast genome and its genetic and intronic composition as well as synapomorphic indels in coding regions (Turmel et al. 2005, 2007, Adam et al. 2007). In the opinion of some researchers (Goncharov 2009), this result is difficult to explane from position of traditional views on the course of the Streptophytes' evolution. Coleochaete and Chara have more complex structures of the thallome than the conjugate. Their mechanism of cell division and other phenotypic features are common with land plants (McCourt et al. 2004). They also tried to resolve issue of the origin and early family relationships of terrestrial plants using the principle multigene phylogenetic analysis according to a large set of individual genomes and morphological characteristics, confirming the deep phylogeny of plants (Finet et al. 2010). A larger number of available special sequences (ESTs) and samples of different genes from a large number of taxa 77 nuclear genes from 77 different taxa) were selected and new transcript data of pyrosequencing in 5 selected charophytic species of algae, which

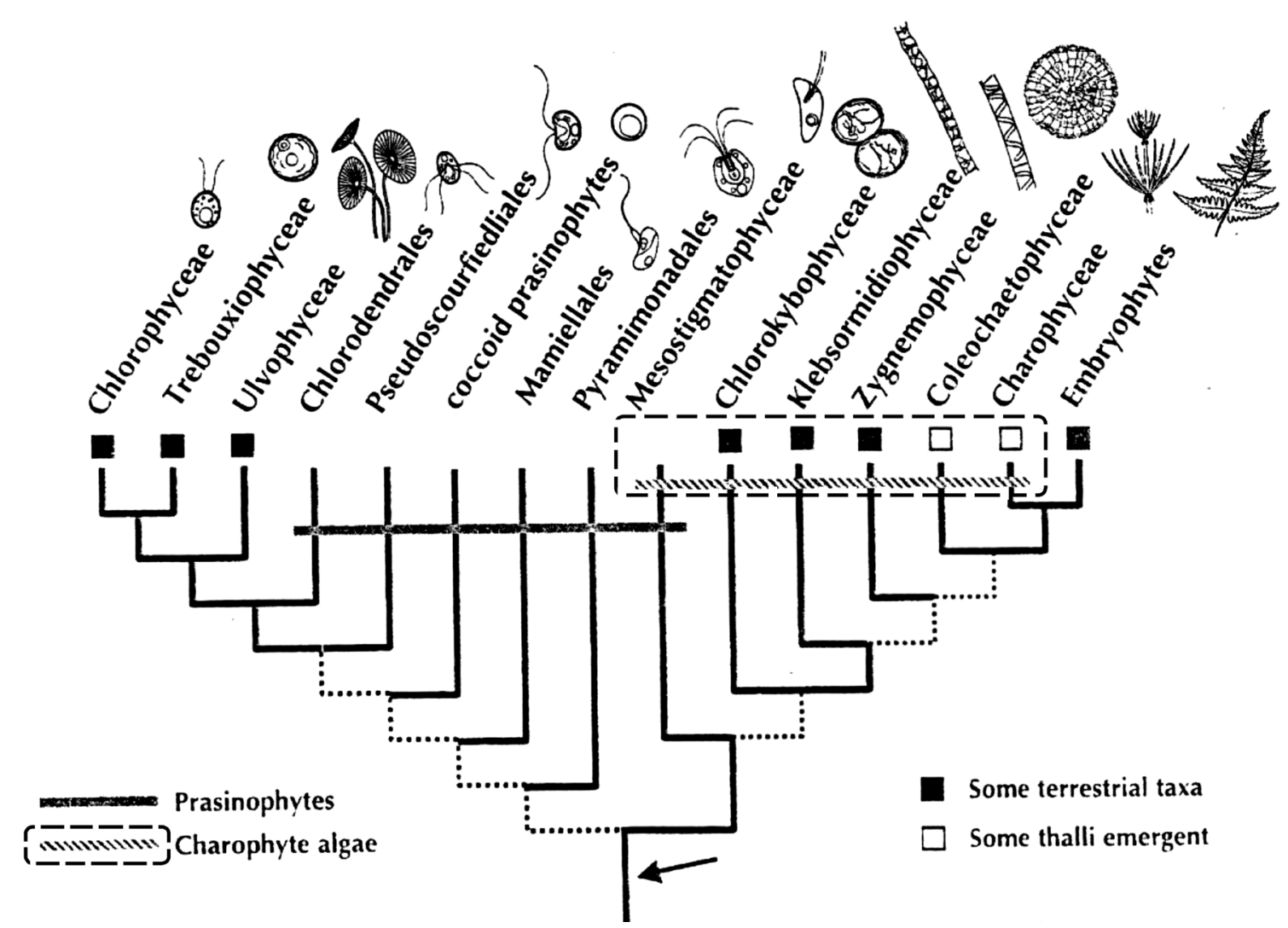

Figure 1 Generalized data on phylogenetic relationships among the main lines of green algae established by analyzing nucleotide sequences of DNA. Branches of a tree (dotted line) show relationships weakly supported by molecular data. Dotted lines inside charophytic algae (dashed line) indicate an insufficiently elucidated site based on the data according to Karol et al. (2001). Arrow at the tree base indicates possible place of Mesostigma (Lemieux et al. 2000, Turmel et al. 2000). Squares at the end of branches show lines containing some soil taxa (dark squares) or taxa which occurred from them (light squares). The absence of squares means that all taxa in the group are aquatic organisms (according to Lewis \& McCourt 2004) 


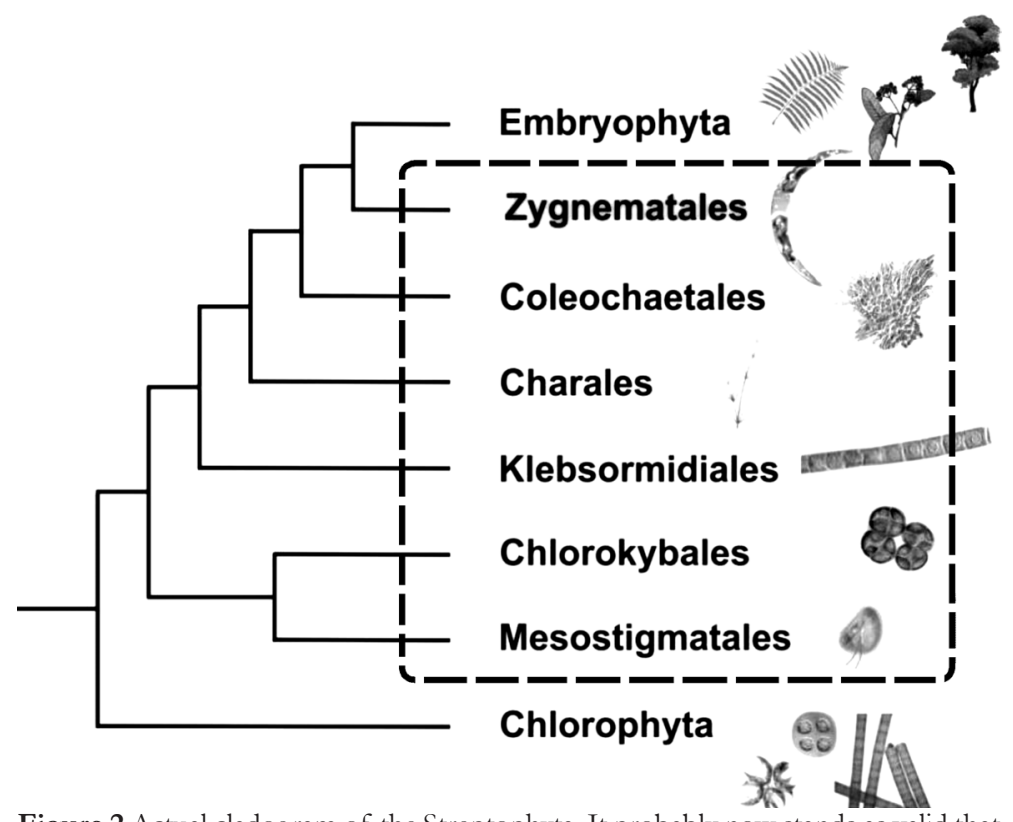

Figure 2 Actual cladogram of the Streptophyta. It probably now stands as valid that a Charales-line broke away before both lines of Coleochaetales and Zygnematales (according to Gontcharov 2008) related to Charophytes (dashed line).

are the main representatives in the decision of origin of the terrestrial plants. Phylogenetic analysis of these multigene data supported Coleochaetales as close relatives of terrestrial plants with bootstrap support $91(\mathrm{BP}=91)$. The authors used a site-heterogeneous model of evolution (CAT), which showed the best results (likelyhood=96.39) for the first time. The phylogenetic clade of Coleochaete as a closely related group to land plants appeared to be extremely expressed in these assays, and finally became a "model and taxonomic model" of plants. The authors emphasize that the species of Coleochaete and terrestrial plants have many similarities. The morphological features such as complexity of threedimensional organization of the body with parenchymashaped tissue are major properties that are common for both phylogenetic clades members.

An ultrastructural study showed that mitosis and cytokinesis cells in Coleochaete takes place by type of phragmoplast that is very similar to cytokinesis of terrestrial plants. In addition, the Coleochaete cells contain peroxisomes, which are inherent terrestrial plants. The sister relationship of Coleochaete also is possibly based on the results of paleontological researches. For instance, the fossil representatives from Parka genus from late Silurian - Early Devonian were compared with modern Coleochaete based on two structures of generative organs and ecology and reaffirmed that they can be the parent group of the charophytes (Taylor 2009). Introns of mitochondrial genes of nad5, discovered in Coleochaete orbicularis Pringsh., Sphagnum, and Marchantia, were not found in other Charophytes and in some Embryophyte that can be results of secondary loss during evolution. Two orders, Mesostigmatales and Chlorokybales, do not represent majority in the upper clade as has been mentioned by above authors and this is different from the modern phylogeny which is based on the structure of the chloroplast genome. The authors of this paper consider that Mesostigmatales location as out-groups to the other Charophytes are supported by the presence of their autonomic mobile stage, but in future assays the position of these two groups should be clarified (compare with Wickett et al. 2014). Topology of these studies demonstrated that Mesostigmatales, Chlorokybales, and Klebsormidiales participated in early divergence from the Charophyte lines. They found congruence with the nuclear localization of gene tut $\mathrm{A}$ in late-divergent Charophyte lines and terrestrial plants. Unexpected in these studies was the grouping of Zygnematales along with Chaetosphaeridium, which was formally approximated to Coleochaetales. Confirmation of these data will be of great significance for charophytes taxonomy (Finet et al. 2010).

Recently, a team of researchers from various institutions in New Zealand and Italy tried to determine the value of the potential effect of "long-branch attraction" for building phylogenetic reconstructions. The chloroplast genome was done for this analysis, including three new chloroplast genomes of Streptophyte algae: Coleochaete orbicularis Pringsheim, Nitella hookeri A. Braun, Spirogyra communis (Hassall) Kütz. Thus, site- and time-heterogeneous model of order differences Streptophyte and terrestrial plants were used. These analyses supported the hypothesis, based on data from nuclear sequent or just about Zygnematales, or clade Coleochaetales plus Zygnematales, as firmly united groups of terrestrial plants (Zong et al. 2013).

These examples of phylogenetic studies of kinship ties of Charophyte algae along with terrestrial plants suggested that the question of who is the sister group of the terrestrial plants is not yet completely resolved, but obviously will be decided in the following phylogenetic studies.

\section{Evolution of the charophytes}

Recent developments in the evolutionary study in the end of twentieth century that were based on morphological features of plants lets to formulate a obvious idea of the main phylogenetic lines of photosynthetic eukaryotes (Mishler \& Churchil 1985, Bremer 1985, Graham et al. 1991, Kenrick \& Crane 1997). Morphological studies of cladists are significantly outstripped the traditional taxonomy, strengthened and clarified the criteria for identifying characteristics of homology clearly outlining certain monophyletic groups, but often provided erroneous interpretation of some features in evaluations and presented a doubtful value of homoplasy in plant evolution (Qui 2008). In contrast, molecular phylogenetic studies were based on the structural changes of genomes contributed to the deepening knowledge and accuracy of analysis and interpretation of the results (Qiu et al. 1998, 2000, 2007, 2008, Bowe et al. 2000, Chaw et al. 2000, Graham \& Olmstead 2000, Karol et al. 2001, Hilu et al. 2003, Kelch et al. 2004). These molecular studies contributed adjustments or clarified controversial conclusions of cladistic investigations by a combination of morphological and molecular data and led to the rapid growth of knowledge on the evolution and the relations between organisms. 


\section{The evolution of life cycles}

The type and nature of the life cycle of the organism is considered the leading feature of its identity and help reveal a better understanding of its evolution. Changes in the life cycles of different lines of Streptophyte organisms are considered one of the most interesting and important aspects of plant evolution. Phylogenetic analysis of recent Charophyte algae and the specificity of life cycles in their fossil representatives demonstrate a trend of expansion of diploid sporophyte generation (Manhart \& Palmer 1990, Melconian et al. 1995, Chapman et al. 1998, Karol et al. 2001, Lemieux et al. 2007, Turmel et al. 2007, Qui 2008).

The phylogenetic relationship between charophytic algae and early terrestrial plants, which were confirmed by morphological and molecular data, has shed light on two major events in the history of plant life: output of plants to land and changes from vegetative haploid with zygotic meiosis, typical for charophytes, to diploid sporophytes as the dominant generation in the life cycle of terrestrial plants (Fig. 3).

Charophytic algae are usually referred to as a vegetative haploid of meiosis in the zygote. However, evidence to defend this interpretation is very scarce, despite its broad support in scientific references. General knowledge sometimes becomes collective misinformation when numerically small, poorly evidenced ideas are based on alleged ambiguous assumptions. They acquire the status of generally accepted ideas, which is typical for some preceding cytological observations (Farley 1982). A generally accepted legend is correct when it concerns the chromosome reduction in zygotes, but concluding that vegetative cells of algae are always haploid are based on assumptions refuted by a number of published studies that do not coincide with the accepted lifecycle assessments to charophytes (Haig 2010).

Our knowledge on life cycles of charophyte algae is incomplete (Haig 2010). For instance, sexual reproduction has never been described in such important taxa as Mesostigma viride and Chlorokybus atmophyticus, and syngamy, which was described for Chaetosphaeridium and Klebsormidium (Tompson 1969, Wille 1912) but did not include information on the number of chromosomes in different phases of the life cycle of algae. Recently, Haig (2010) made a detailed review of published studies on the life cycles of many algae, including Charophytes, focusing on the "uncommonly accepted" life cycle described in the terminology for terrestrial plants. The author suggested that each life cycle of the algae passes differently because of increased sensitivity to possible changes in the environment. He conducted the molecular phylogenetic study of a number of Charophyte algae and showed the various options of life-cycle processes that do not coincide with the commonly asserted opinion (Haig 2010: 861). These examples demonstrate that life-cycle processes of the Charophyte algae requires further thorough studies, especially in view of the widespread phenomenon of cytological polymorphism in numerous Charophytes, such as desmids algae (Palamar-Mordvintseva 1980, 1982).

According to the results of molecular phylogenetic studies of the last decade, it has been shown that the embryophytes emerged from Charophyte algae (Karol et al. 2001, Qiu et al. 2007, Qiu 2008, Becker \& Marin 2009). At the same time, Charophyte algae (Charales) are characterized by development of its life cycle with the vegetative haploid cells and diploid zygotes. Such a cycle of development is the most accepted by researchers as algal ancestor of embryophytes and regarded as one of the criteria to support the theory of the origin of sporophytes (Qiu 2008, Haig 2008, 2010, Becker \& Marin 2009). However, phylogenetic analyses regarding Charales or alternative Coleochaetales and Zygnematales, which are also indicated as a sister group of terrestrial plants, depending on the quantity and quality of samples of studied genes, and taxa have not received strong statistical support.

In our own experience of molecular studies of the Charophytes, we revealed that the species of the genus Chara in Israelian populations, for example, are well separated from one another according to Amplified Fragment Length Polymorphism (AFLP) analysis (Yehuda et al. 2013). This allows us to assume that the most general, systemic approach in molecular studies of the Charophyte algae is adequate for morpho-ecological species taxa definition.

Although analyses of chloroplast genes demonstrated statistical support for Zygnematalean algae (based on order of gene placement in chloroplast genome and its gene and intron composition and synapomorphic indels (insertions and deletions) in coding regions), or clade showing that Zygnematales and Coleochaete are sister groups of embryophytes (Turmel et al. 2005, 2007, Adam et al. 2007, Rodriguez-Ezpeleta et al. 2007, Gontcharov 2009). Further studies of larger series of taxons and genes (Becker \& Marin 2009) demonstrated Charales as the sister group of terrestrial plants, emphasizing the progressive evolution of cellular complexity in the Charophytic algae (phragmoplast, plasmodesm, six-time cell synthesis, structure of flagella cells, oogamy, sexual reproduction with the zygote meiosis) and physiological specificity. Along with this, the current studies of plastid genes confirm (Ruhfel et al. 2014) that Zygnematophyceae is a sister clade of a higher terrestrial plants clade: Coleochaetophyceae - to Zygnematophyceae plus Embryophyta; Charophyceae - to Coleochaetophyceae plus (Zygnematophyceae plus Embryophyta); and clade Mesostigmatophyceae plus Chlorokybophyceae - for all other Streptophyta (with bootstrap-support about $86 \%$ ) (Fig. 4).

These results once again highlight the disparity in representations of phylogenetic relationships of different Streptophyta representatives based on molecular-genetic data with classical morphological and cytological characteristics and ambiguity in the determination of relationships among this group of plants as well as the need to involve the analysis of other genes.

\section{Multicellularity}

One of the important events in the evolution of charophytic algae was the transition from unicellular organisms to a multicellular state existence that occurred before the plant emerged on the land. Contemporary phylogeny suggests that the emergence of plants on land occurred by a common ancestor for all Streptophytes, and these ancestors were probably algae with a sarcinoid organization of cells, such as in Chlorokybus atmophyticus, representing a set of cells connected by plasmodesms, and forming an appropriate state of multicellularity (Qiu 2008, Becker \& Marin 2009). 


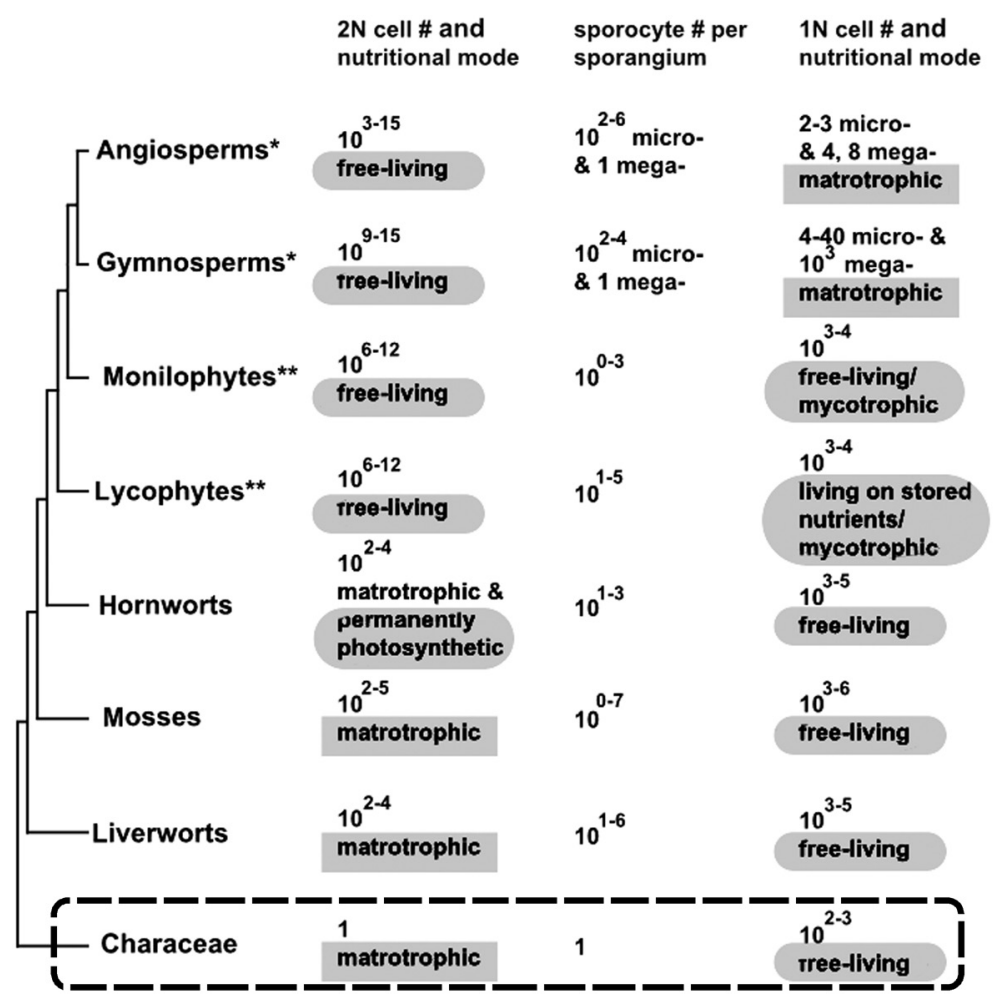

Figure 3 Evolutionary trends of size and nutritional mode of the diploid and haploid phases and sporocyte (meiocyte) number per sporangium in streptophytes (land plants) (according to Qiu et al. 2008). The phylogeny is based on information reviewed in Qiu (2008), Charophytes are marked by dashed line

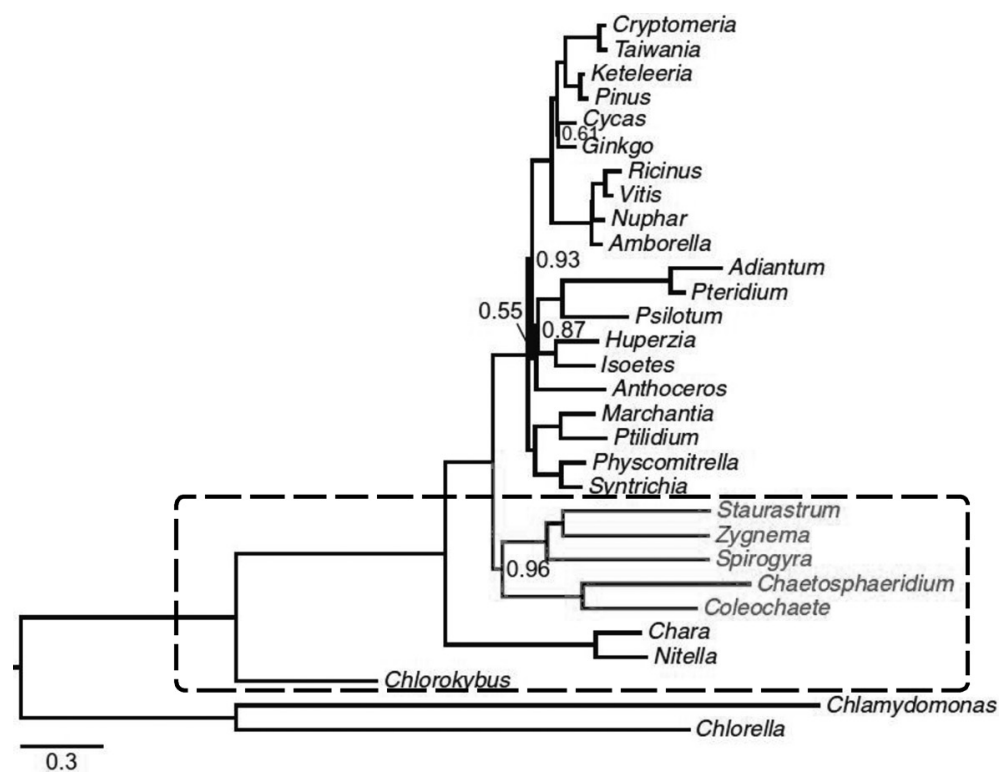

Figure 4 Phylogenetic trees using the site-heterogeneous model (i.e. the CAT-GTR model) in PhyloBayes and time-heterogeneous model in nhPhyML based on the full $(45,879$ aligned sites) and OV-sorted (36,879 aligned sites) matrices. Numbers on the tree indicate the Bayesian PP from PhyloBayes and the ML BP from nhPhyML, and nodes with $100 \mathrm{BP}$ or 1.0 PP are not marked (according to Zong et al. 2013).Charophytes are marked by dashed line

Formation and improvement of multicellularity depended on two main processes at the cellular level: the combination of cell formation and cellular information exchange (Alberts et al. 1989, Grosberg \& Strathmann 2007). Nowadays, it is difficult to establish the real path of the cells' combination process in the earliest charophytes, but information on in- dividual physiological and biochemical features is available.

Particularly, there is information about a plasmodesm cytoplasmic bridge, which connects cells and allows the exchange of hormones, RNA, carbohydrates, proteins, and other components between cells (Lucas \& Lee 2004). The evolution of this method of communication between cells in the early charophytes undoubtedly contributed to the successful formation of a large multicellular organism's complex in them. Among all, modern charophytic Mesostigma viride is perhaps one of the ancestors of unicellular plants. Along with this, Chlorokybus atmophyticus, a sarcinoid, is the representative of occurrence in the primitive type of multicellularity in the Charophytes. Modern studies of charophytes phylogeny and terrestrial plants predict that plasmodesm occurred in the common ancestor for Coleochaetales, Charales, and terrestrial plants (Qiu 2008).

Equally important, but rather essential for the evolution of Charophyte multicellularity and the formation of three-dimensional body of plants generally, was the phragmoplast, which is a special adaptation in the form of vesicles and microtubules formed during cytokinesis (Pickett-Heaps 1975). This process of interaction between cells was found in Zygnematales, Coleochaetales, Charales, and terrestrial plants (Marchant \& Pickett-Heaps 1973). It is assumed that the emergence of phragmoplast contributed to the formation of two- or threedimensional organisms' aggregates of cells during their division, with further development of the integrated plant's thallome (Hageman 1999, Pickett-Heaps et al. 1999).

The development and establishment of these structures were held, apparently, independently of one another, and had a leading role in the formation of charophytes multicellularity. Identification of code genes' various components of both structures has greatly increased the understanding in how the stepby-step multicellularity of photosynthetic eukaryotes promoted the transition from aquatic to land habitats. The accumulation of knowledge about the biology of cells over the past years of the 20th century and the first years of the 21 st century laid the foundation for understanding the transition from unicellular to multicellular organisms (Phickett-Heaps et al. 1999, Lucas \& Lee 2004, Qiu 2008). It should be emphasized that the transition from unicellularity to multicellularity actually happened twice during the evolution of the Streptophytes: once on the gametophyte level of organisms during the early evolution of Charophytes, and the second time on the sporophyte level during the evolution of terrestrial plants (Qiu 2008). With time, the life cycle of diploid sporophytes became dominant 
in the life of terrestrial plants (McManus \& Qiu 2008), and the emergence of lignin promoted the formation of the multicellular body of plants.

Gravitropism, as a process of response in organism to gravity, has played a decisive role in the formation and evolution of the plant body with a vertical axis of the stem and photosynthetic organs (leaves) in the air and by strengthening absorptive rhizoids or roots, a period when Charophytes (Streptophytes) moved from free-floating planktonic forms (e.g. Mesostigma viride, or representatives of Zygnematales) to aquatic Charophyte rhizophytous algae and other terrestrial Streptophyta (Raven \& Edward 2001). Gravitropism origin and evolution explanations for Streptophytes allow us to understand its role in defining the general evolution of life on the planet (Qiu 2008).

Charophyte algae and terrestrial plant phylogeny in modern reconstructions (Qiu 2008) suggests that Streptophytes' gravitropism evolved from a common ancestor for Charophytes and terrestrial plants, as both these groups are Rhisophytes (Raven \& Edwards 2001), while others are freely floating Charophytes, planktonic organisms, or epiphytes in aquatic or terrestrial habitats (Van den Hoek et al. 1995). Some early phylogenetic studies of the Charophyte algae, using data from nuclear $18 \mathrm{~S} \mathrm{rDNA}$, reveal that the Characeae familyappear as the first line of divergence among Charophytes (Kranz et al. 1995, Friedl 1997). Such a scenario was not the only one to be accepted because Rhisophytes had been identified, and among Chlorophyta (Raven \& Edwards 2001), and gravitropism, apparently, did not evolve once in all eukaryotes. However, there is strong support in the two multigene studies confirming the Characeae position as the sister group for terrestrial plants (Karol et al. 2001, Qiu et al. 2007). These hypotheses suggest that gravitropism evolved only from one of the Streptophyte algae representatives but confirm the Charophytes position as a sister group for terrestrial plants (Qiu 2008, Becker \& Marin 2009, Haig 2010). Gravitropism of Charophytes was studied in great detail at the cellular level (Braun \& Limbach 2006). As a result, similar signs of gravity and polarization cell growth in this system were discovered. Actomyosin played a key role in the perception of gravity in the first coordination position of the statolith, which was a blister filled with crystals. When changing the orientation of cells relative to the gravity direction towards the statolith deposition, the specific location of the membrane plasma makes contact with the boundary membranes as a result of gravity-sensor molecular call (Qui 2008). Some researchers have found an auxin role in the regulation of rhizoid growth and expression of gravitropism in Chara species (Klambt et al. 1992, Cooke et al. 2002).

Detailed studies of genetics and cell biology gravitropism in Characeae and Arabidopsis thaliana (Galweiler et al. 1998, Friml et al. 2002, Paponov et al. 2005, Palme et al. 2006) contributed large-scale studies of this phenomenon of evolution. According to current data, the hypothesis that Characeae gravitropism is also represented in all terrestrial plants controlled by the same genetic mechanisms as in other Streptophyta, is supported.

Total sequence evolution of auxin metabolism evolution and its presence in Charophytes and other plants also indicate support of this hypothesis, and the presence of similar morphological organs (rhizoid or roots) - the presence of positive gravitropism (Cooke et al. 2002, Qiu 2008). Gravitropism phenomenon, which emerged in algae before they came onto the land, helped them to evolve and adjust to complexities of another environment (drying, insufficient nutrition, etc.) under terrestrial existence.

The gravitropism of the charophytes is often investigated when the thalluses developed well in the optimal environmental variables and therefore formed massive grows (Fig. 5). On the other hand, an attempt to emerge on land was associated with the impact of ultraviolet radiation, which is not so strong in temperate climatic zones but is increased in arid areas, such as the desert belt of Eurasia. Therefore, our investigation on charophytes expands to deserted populations, such as the Dead Sea area, the lowermost Charophytes locality in the world, and shows that it is not only under high insolation but also under decreasing sunlight during the sandstorms that periodically come from the Sahara Desert, from the Arabian Desert across the Negev Desert (Krasnov et al. 2014). Massive dust transportation not only covers large deserted areas (Faiman 1998), such as in the Arava Valley, but also decreases in sunlight intensity during the day. It is especially important in the lowermost area near the Dead Sea in which light intensity decreased $25 \%$ (Boykiw 2011) as a result of the dust layer thickness, which is more than $250 \mathrm{~m}$. Therefore, here we can see the largest amplitude of sunlight intensity in the natural environment in which the charophytes demonstrated its mechanism of resistance.

As a protected mechanism, algal cells formed special compounds (Karsten \& Garcia-Pichel 1996) as a response to the UV-radiation impact (Klish et al. 2002), on the one hand, and negatively reacted to sunlight inhibition on the other hand. Increasing UV-radiation effects include inhibition of photosynthesis, inhibition of growth, and DNA damage. As a result, algae have developed a mechanism of avoidance as well as adaptation to light intensity fluctuation during its evolutionary process. It especially relates to the charophyte species definition and ecological preferences.

For example, it is well known that Chara vulgaris L. and C. contraria A. Braun ex Kütz. are two cosmopolite species that are sometimes difficult to distinguish one from the other (Grant \& Proctor 1972). Moreover, these species often occupied the same habitat, as we revealed in the Negev Desert stream Ein Avdat (Barinova et al. 2010, Yehuda et al. 2013). Because each charophyte species evolved in the presence of UV radiation, a multitude of adaptive strategies had been developed, which allowed them to exist under sunlight exposure (C. vulgaris) or in less exposed places (C. contraria) (Krause 1997) and the repair of DNA damage as a result of developing a major mechanism of UV adaptation (Klish et al. 2002). As was found in our research for the Avdat stream with AFLP analysis, the charophyte populations were divided into clusters corresponding to the levels of light intensity over the shadow gradient in this deep canyon in the Central Negev. Therefore, we can assume that environmental preferences of both morphologically similar species of Chara are entrenched in the process of evolution as a result of repairing injured 

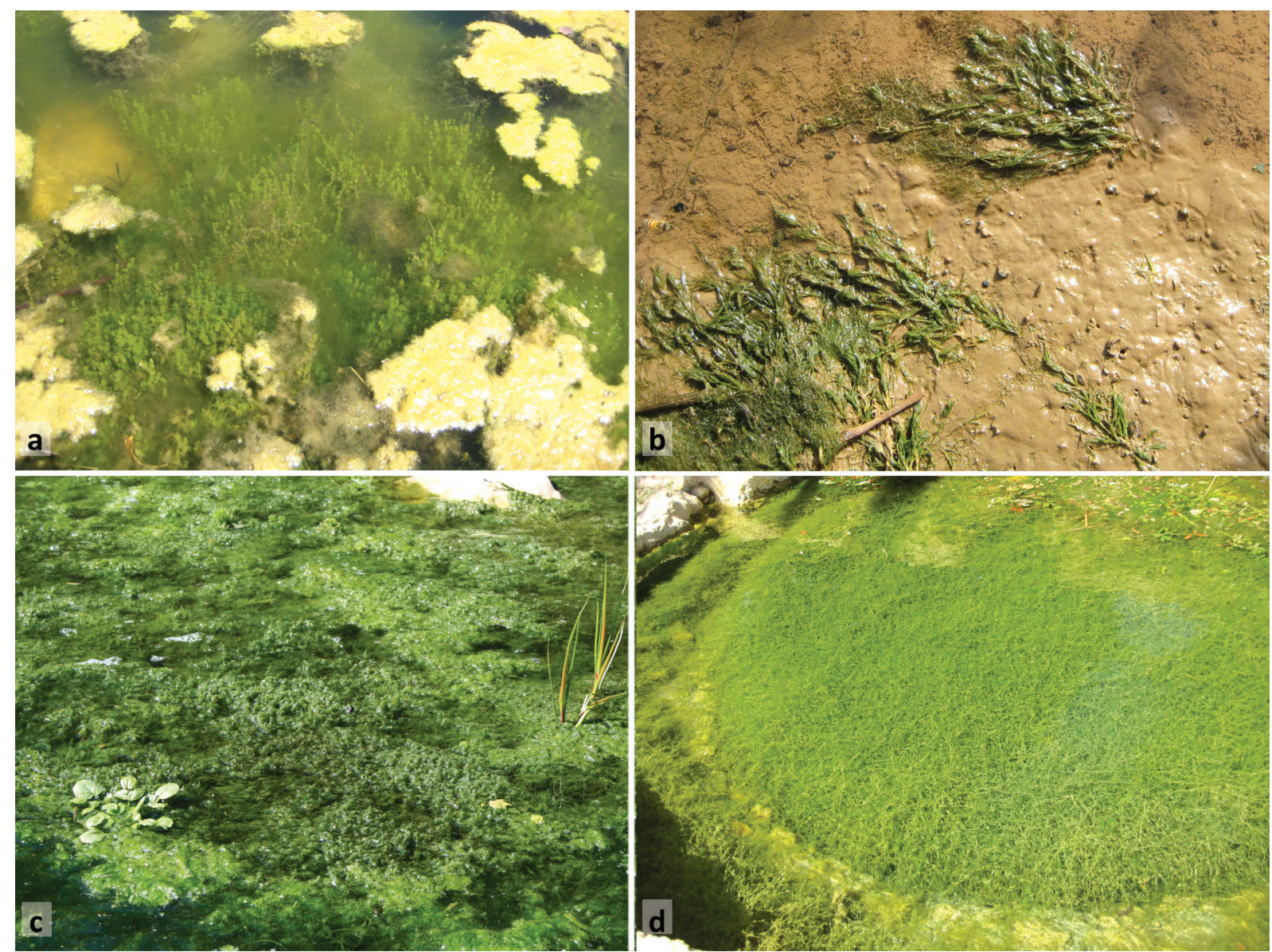

Figure 5 Positive gravitropism of the Charophyte algae (a - Chara vulgaris L. in the Oren River pool), surviving in the terrestrial habitat occupation ( $\mathrm{b}$ - Chara grovesii B.P. Pal, the Ga'aton River), positive phototropism (c - Chara gymnophylla A.Braun in the Nevoria pool, Northern Israel), negative phototropism ( $\mathrm{d}$ - Chara vulgaris in the Neot Zmadar pool, Southern Negev Desert)

DNA by ultraviolet radiation and subsequent consolidation of other features. As a result, we are seeing the shade-tolerant C. contraria in the Arava Valley inhabiting the lowest place in the world that is affected by the shading of the dust layer more than 500 meters thick. We compare these species geographic ranges and ecological characteristics in the Negev Desert and found out that C. vulgaris inhabits northern mountains (Barinova \& Romanov 2014ab) as well as the southern uplands (Barinova \& Romanov 2015a), but always in welllighted habitats, whereas $C$. contraria prefers shadowed habitats, such as Ein Avdat canyon or Neot Ha Kikar pool (Barinova \& Romanov 2015b) in the lowermost Arava Valley sites, and therefore have the mechanism of avoiding ultraviolet damage. More of them, if in the future there will be a global warming change, $C$. vulgaris can be a winner in the adaptation process (Joye \& Rey-Boissezon 2015) more than C. contraria.

\section{Phylogenesis and evolution of Charales}

Studying contemporary Charophyte algae was associated with increasing knowledge of evolution in the geological past. Charophytic algae are an ancient group of plants, which held a special independent path of evolution, as evidenced in their fossils.

The first single fossil remains of charophytes, such as gyrogonites, are known from Silurian sediments of the $\mathrm{Pa}$ leozoic era, and their remains are well-preserved as a large number were already in the Devonian. Studying charophytic fossils was particularly actualized in the second half of the 20th century because it was found that the gyrogonites managed to trace a complex history of the evolution of these plants. Separated from the other groups in green algae in the first period of the Paleozoic era (about 725-1200 million years ago), charophytic algae overcame difficulties in its evolution in different conditions of the environment and have been preserved up-to-date (Maslov 1963, Saidakovsky \& Shaikin 1976, Shaikin 1987, Yoon et al. 2004, Zimmer et al. 2007). They are found in the geological strata of the Paleozoic era ranging from the upper Silurian Paleozoic to Anthropogene in about 420-450 million years ago. Their development is characterized by active stages of flowering (Devonian, the early Triassic, late-Jurassic, Cretaceous and Eocene periods) and a calmer development in subsequent periods (Kyansen-Romashkina 1981).

The most ancient representatives of Charophyte orders, such as Sycidiales and Trochiliscales from the upper Silurian (age about 420 million years), had already built quite a difficult female reproductive organ, indicating the earlier, yet unknown to science stage in the evolution of Charophytes. In the Devonian period, wide development of high-ranking Charophytes was found: seven families with small numbers of genera. Instead of the above-mentioned orders, Charophytes with curled left partecalcines, namely Charales, have appeared. Their development is characterized by a progressive decrease in the number of partecalcines with $8-13$ in the Devonian 
Zocharas, to the 6th coal paleocharas and its stabilization for 5th of all four Meso-Cenozoic families. The Mesozoic age was marked by the development of the Porocharaceae family, which gave rise to new phylogenetic lines in the Jurassic period. In Meso-Cenozoic sediments, forms over 230 million years, four families of Charophytes and more than 90 genera were established. Although the origin of the Porocharaceae family was indicated in the Paleozoic, about 9 genera appeared in the early Mesozoic Era in continental waters and favorable conditions.

In the Jurassic period the pace of development of the family diminished, but new phylogenetic lines that gave rise to Clavatoraceae, Raskyellaceae and Characeae families appeared. Fifteen families, 7 genera of which existed 5.7 million years ago, while others existed 20-30 million years ago appeared in the late Jurassic period in the early Cretaceous period. The Characeae family slowly evolved relatively in the Jurassic period: two families appeared at the beginning of the period (180 million years ago), and $2-$ at the end of the period. In the late Cretaceous period rapid development of this family occurred - 20 new genera appeared, which apparently were connected with favorable paleogeographic conditions existing at the time. The Characeae family replaced two families previously endangered in the habitats. They were extinct in the Eocene, which lasted 220 and 100 million years, respectively. Charophyceae family ranked a dominant place among Charophytes, but the pace of its development began to gradually decline and families became extinct over the appearance of new ones. In the late Neogene family composition dramatically decreased and approached that of today. Four ancient families continued to exist and lived up until the present time with an approximate continuation of existence: Lamprothamnium - 80, Nitellopsis - 65, Chara - 55, and Lychnothamnus 25 million years.

The maximum developmentand diversity of Charophytes were observed in the Devonian period. At the end of the Paleozoic extinction representatives of Charophytes were represented by two orders, and further evolution in the Mesozoic and Cenozoic were mainly characterized by species of the family Characeae development. The most intensive genus development of Charophytes and their revival occurred in Late-Jurassic and Cretaceous periods. The dominant development of the Characeae family marked the turn of Mesozoic and Cenozoic periods (Saidakovsky \& Shaikin 1976).

After separation from the ancient marine Chlorophytes (Chlorophyta), the Charophyte algae lived in freshwater habitats in the world and were the only environments for eukaryotes before the Cambrian period. They coexisted alongside their embryophyte descendants that appeared perhaps earlier than the first water Embryophytes (MartinClosas 2003), and also earlier than its marine Chlorophyte sisters. The extinction of Charales with an antisentinel oogonium took place was the Permian and Triassic periods. Approximately 65 million years ago, a time known as the end of the Mesozoic dinosaurs, the Clavatoraceae family of Charophytes became progressive extinction and reduction survived Charophytes (Martin-Closas 2003, 2008) and obviously many ancient mass extinct Charophyte algae, mic- roscopic residues of which were not found in fossil subsoils. As a result, studying fossils from various countries descriptions of 3 orders, 12 families, more than 115 genera and over 600 fossil Charophyte algae species were made (Saydakovsky 1993). Contemporary Charophytes are presented by 1 order, 1 (3) families, 6 genera and 300 (440) species. Therefore, according to paleontological researches it can be argued that modern Charophyte algae are remnants of the former diverse group of flower plants

\section{Conclusions}

Charophyte algae and terrestrial plants form one (Streptophytes) from phyla of eukaryote evolution and embrace the diversity of single-celled algae to advanced angiosperms. Classic morphological and taxonomic ideas of direct family relations of Charophyte algae (Charales) with higher spore plants or consideration of the group as direct ancestors of "higher plants" were not confirmed by molecular biological researches and data from these investigations are not consistent with traditional morphological and cytological ideas. Currently, there is no common opinion on a specific sisterly group of Charophyte, which was phylogenetically connected with other plants. In addition to the traditional line of Characeae - land plants are enough of a reason (on molecular genetic level) for consideration of sisterly phylogenetic lines from different taxonomic Charophyte groups - Zygnematales/Zygnematophyceae, Coleochaetales or Coleochaetales plus Zygnematales. Studying the interactions of organisms and the ways and mechanisms of evolutionary processes outlined in a huge variety of organisms of Streptophyta in general, and in particular with investigations involving the additional set of genes and modern approaches of their analysis, are some of the main tasks at the current level of understanding the evolution of life on Earth: processes of organisms in general adaptation to the current environment and in establishing relationships.

\section{ACK N O W LE D G E M E N TS}

This work was partly funded by the Israeli Ministry of Absorption and Israel Taxonomic Initiative Fund.

\section{LITERATURE CITED}

Adam, Z., M. Turmel, C. Lemieux \& D. Sankoff 2007. Common invervals and symmetric difference in a modelfree phylogenomics, with an application to streptophyte evolution. Journal of Computational Biology 14:436-445.

Alberts, B., D. Braiy, J. Levis et al. 1989. Molecular biology of the cell. 2nd ed. Garland Publishing, New York, 1218 pp.

Barinova, S. \& R. Romanov 2014a. A new Chara locality in the protected area of the Galilee Mountains, Israel. Natural Resources and Conservation 2(5):80-85.

Barinova, S. \& R. Romanov 2014b. Unique locality with charophytes in the Mount Arbel National Park, Israel. Elixir Bio Diversity 77:28932-28936.

Barinova, S. \& R. Romanov 2015a. How a new locality of algal community in the Negev Desert, Israel was formed. Expert Opinion on Environmental Biology 4(2):1-7.

Barinova, S. \& R. Romanov 2015b. Charophyte community in the lowermost locality in the world near the Dead Sea, Israel. International Journal of Plant \& Soil Science 6(4): 229-243. 
Barinova, S.S., G. Yehuda \& E. Nevo 2010. Comparative analysis of algal communities of northern and southern Israel as bearing on ecological consequences of climate change. Journal of Arid Environment 74:765-776.

Bateman, R.M., P.R. Grane, W.A. DiMichele et al. 1998. Early evolution of land plants: phylogeny, physiology and ecology of the primary land radiation. Annual Review of Ecology, Evolution, and Systematics 29:263-292.

Becker, B. \& B. Marin 2009. Streptophyte algae and the origin of embriophytes. Annals of Botany 103: 999-1004.

Bhattacharya, D. \& L. Medlin 1998. Algal phylogeny and the origin of land plants. Plant Physiology 116: 9-15.

Bhattacharya, D., B. Surek, M. Rusing et al. 1994. Group 1 introns are inherited throught common aycestry in the nuclear-encoded rRNA of Zygnematales (Chlorophyta). Proceedings of the National Academy of Sciences of USA 91(21):9916-9920.

Bold, H.C. \& M.J. Wynne 1985. Introduction to the algae. Prentice-Hall, New Jersey, 720 p.

Bowe, L.M., G. Coat, C.W. de Pamphilis 2000. Phylogeny of seed plants based on all three genomic compartmens: Extant gymnosperms are monophyletic and Gnetales closest relatives are conifers. Proceedings of the National Academy of Sciences of USA 97:4092-4097.

Boykiw, E. 2011. The effect of settling dust in the Arava Valley on the performance of solar photovoltaic panels. The Senior Thesis in Department of Environmental Science Allegheny College Meadville, Pennsylvania, USA, 36 pp.

Braun, M., C. Limbach 2006. Rhisoids and protonemata of characean algae model cells for research on polarized growth and plant gravity sensing. Protoplasma 229: 133-142.

Bremer, K. 1985. Summary of green plant phylogeny and classification. Cladistics 1: 369-385.

Bremer, K.C., I. Humphries, B.D. Mishler \& S.P. Churchill 1987. On cladistic relationship in green plants. Taxon 36: 339-349.

Brinkmann, H. \& H. Philippe 2008. Animal phylogeny and large-scale sequencing progress and pittfals. Journal of Systematics and Evolution 46:274-286.

Chapman, R.L., M.A. Buchheim, C.F. Delwiche et al. 1998. Molecular systematic of the green algae. In: The molecular systematics of plants. 2 (D.E. Soltis, P.S. Soltis \& J.J. Doyle, eds.), pp. 508-540, Kluver Acad. Publ., Massachusets.

Chaw, S.M., C.L. Parkinson, Y.C. Cheng et al. 2000. Seed plant phylogeni inferred from all three plant genomes: Monophyly of extant gymnosperms fnd origin of Gnetales from conifers. Proceedings of the National Academy of Sciences of USA 97: 4086-4091.

Coocke, T.J., D. Poli, A.E. Sztein \& J.D. Cohen 2002. Evolutionary patterns in auxin action. Plant Molecular Biology 49: 319-338.

Darwin, C. 1859. On the origin of species by means of natural selection. London. 556 pp.

Delsuc, F., H. Brinkmann \& H. Philippe 2005. Phylogenomics and the reconstruction of the tree of life. Nature Reviews Genetics 6:361-375.

Delviche, C.F., L.E. Graham \& N. Thomson 1989. Ligninlike compounds and sporopollenin in Coleochaete, an algal model for land plant ancestry. Science 245:399-401.

Faiman, D. 1998. Solar Energy in Arid Frontiers: Designing a Photovoltaic Power Plant for Kibbutz Samar, Israel. In: The Arid Frontier: Interactive Management of Environment and Development, (Bruins H.J. \& H. Lithwick, eds.), pp. 321336. Kluwer Academic Publishers, Boston.

Farley, L. 1982. Gametes and spores. Ideas about Sexual Reproduc- tion. Johns Hopkins University Press, Baltimore, 299 pp.

Finet, C., R.E. Timme, C.F. Delwiche \& F. Marlétaz 2010. Multigene phylogeny of the green lineage reveals the origin and diversification of land plants. Current Biology 20(24): 2217-2222.

Friedl, T. 1997. The evolution of the green algae. Plant Systematics and Evolution (Suppl.) 87:87-101.

Friml, J., J. Wisniewska, E. Benkova et al. 2002. Lateral relocation of auxin efflux PIN3 mediates tropism in Arabidopsis. Nature 415:803-809.

Galweiler, L., C. Guan, A. Muller et al. 1998. Regulation of polar auxin transport by AtPIN1 in Arabidopsis vascular tissue. Science 282:2226-2230.

Gontcharov, A.A. 2008. Phylogeny and classification of Zygnematophyceae (Streptophyta): current state of affairs. Fottea 8:87-104.

Gontcharov, A.A. 2009. Problems of taxonomy of the conjugates (Zygnematophyceae, Streptophyta) in relation to molecular-phylogenetic data. Botanicheskii Zhurnal 94(10): 1417-1438 (in Russian with English summary). [Гончаров А.А. 2009. Проблемы систематики коньюгат (Zygnematophyceae, Streptophyta) с точки зрения момекулярно-филогенетических данных // Ботанический журнал. Т. 94, №10. С. 1417-1438].

Graham, L.E. 1993. Origin of land plants. John Wiley \& Sons, New York, 700 pp.

Graham, L.E., C.F. Delviche \& B.D. Mishler 1991. Phylogenetic connection between the "green flgae" and the "bryophytes". Advances in Bryology 4: 213-294.

Graham, S.W. \& R.G. Olmstead 2000. Utility of 17 chloroplast genes for interring the phylogeny of the basal angiosperms. American Journal of Botany 87:1712-1730.

Grant, M.C. \& V.W. Proctor 1972. Chara vulgaris and C. contraria: patterns of reproductive isolation for two cosmopolitan species complexes. Evolution 26(2):267-81.

Grosberg, R.K. \& R.R. Strathmann 2007. The evolution of multicellularity: A minor major transition? Annual Review of Ecology, Evolution, and Systematics 38:621-654.

Hageman, W. 1999. Towards an organismic concept of land plants: The marginal blasnozone and the development of the vegetation body of selected frondose gametophytes of liverworts and ferns. Plant Systematics and Evolution 216:81-302.

Haig, D. 2010. What do we know about charophyte (streptophyta) life cycles? Journal of Phycology 46:860-867.

Hedges, S.B., J.E. Blai, M.L. Venturi, \& J.L. Shoe 2004. A molecular timescale of eucariote evolution and the rise of complex multicellular life. BMC Evolutionary Biology 4: 2 .

Hennig, W. 1966. Phylogenetic systematics. The University of Illinios Press, Urbana, 263 pp.

Hilu, K.W., T. Borsch, K. Muller, P.S. Soltis, V. Savolainen, M.W. Chase, M.P. Powell, L.A. Alice, R. Evans, H. Sauquet, C. Neihuis, T.A.B. Slotta, R.G. Rohwer, C.S. Campbell \& L.W. Chatrou 2003. Angiosperm phylogeny based on mat $\mathrm{K}$ sequence information. American Journal of Botany 90:1758-1776.

Joye, D.A. \& A. Rey-Boissezon 2015. Will charophyte species increase or decrease their distribution in a changing climate? Aquatic Botany 120:73-83.

Ju, C., B. van de Poel, E.D. Cooper, J.H. Thierer et al. 2015. Conservation of ethylene as a plant hormone over 450 million years of evolution. Nature Plants 1:1-7.

Karol, K.G., R.M. McCourt, M.T. Cimino \& C.F. Delwiche 2001. The closest living relatives of land plants. Science 294:2351-2353.

Karsten, U. \& F. Garcia-Pichel 1996. Carotenoids and my- 
cosporine-like amino acid compounds in members of the genus Microcoleus (cyanobacteria): a chemosystematic study. Systematic and Applied Microbiology 19(3):285-94.

Kelch, D.G., A. Driskell \& B.D. Mishler 2004. Inferring phylogeny using genomic characters: a case study using land plant plastomes. In: Molecular systematic of bryophytes, (Goffinet, B., V. Hollowell \& R. Magil, eds.), pp. 3-11, Missouri Botanical Garden Press, St. Louis.

Kenrick, P. \& P.R. Crane 1997. The origin and early diversification of land plants. Nature 389:33-39.

Klambt, D., B. Knauth \& I. Dittman 1992. Auxin dependent growth of rhizoid of Chara globularis. The Evolution of Plant Physiology 85:537-540.

Klish, M., R.P. Sinha \& D.-P. Hader 2002. UV-absorbing compounds in algae. Current Topics of Plant Biology 3: 113-120.

Kranz, H.D., D. Miks, M-L Siedler et al. 1995. The origin of land plants: phylogenetic relationships among charophytes, briophytes and vascular plants infrrred from complete small-subunit ribosomal RNA gene sequences. Journal of Molecular Evolution 41:74-84.

Krassilov, V.A. 2014. Evolution: System Theory. Pensoft, SofiaMoscow, Bulgaria, 414 pp.

Krasnov, H., I. Katra, P. Koutrakis \& M.D. Friger 2014. Contribution of dust storms to PM10 levels in an urban arid environment. Journal of Air and Waste Management Association 64(1):89-94.

Krause, W. 1997. Charales (Charophyceae). Süßwasserflora von Mitteleuropa, 18. Gustav Fischer Verlag, Stuttgart, 202 pp.

Kyansen-Romashkina, N.P. 1981. Paleoecological peculiarities of Cretaceous and Paleogenic charophytes. In: V sesoyuznoe paleoal'gologicheskoe soveshchanie (Nov. 17-19, 1981, Kiev), pp. 99-100, Naukova Dumka, Kiev (in Russian). [Кянсен-Ромашкина Н.П. 1981. Палеоэкологические особенности меловых и палеогеновых харофитов. Всесоюзное палеоальгологическое совещание (Киев, 17-19 нояб. 1981 г.). Тез. Аокл. Киев: Наук. Аумка. С. 99-100].

Laurin-Lemay, S., H. Brinkmann \& H. Philippe 2012. Origin of land plants revisited in the light of sequence contamination and missing data. Current Biology 22(15): R593R594.

Lemieux, C., C. Otis \& M. Turmel 2000. Ancestral chloroplast genome in Mesostigma viride reveals an early branch of green plant evolution. Nature 403:649-652.

Lemieux, C., C. Otis \& M. Turmel 2007. A clade uniting the green algae Mesostigma viride and Chlorokybus atmophyticus represent the deepest branch of the Streptophyta in chloroplast genome-based phylogenies. BMC Biology 5:2.

Levis, L.A. \& R.M. McCourt 2004. Green algae and the origin of land plants. American Journal of Botany 91:1535-1556.

Lucas, W.L. \& J.Y. Lee 2004. Plasmodesmata as a supracellular control nework in plants. Nature Reviews Molecular Cell Biology 5:712-726.

Manhart, J.R. \& J.D. Palmer 1990. The gain of two chloroplast transfer-RDA introns marks the green ajgae ancesrors of lamd plast. Nature 345:268-270.

Marchant, H.J. \& J.D. Pickett-Heaps 1973. Mitosis and cytokinesis in Coleochaete scutata. Journal of Phycology 9:461-471.

Martín-Closas, C. \& Q. Wang 2008. Historical biogeography of the lineage Atopochara trivolvis Peck 1941 (Cretaceous Charophyta). Palaeogeography, Palaeoclimatology, Palaeoecology 260: 435-451.

Martin-Closas, C. 2003. The fossil record and evolution of freshwater plants: A review. Geologica Acta 1(4):315-338.

Maslov, V.P. 1966. Some Cenozoic charophytes in the south of the USSR and the methods of their studies. In: Fossil charophytes of the USSR, (V.P. Maslov \& V.A. Vakhromeev, eds.), pp. 10-200, Nauka, Moscow (in Russian). [Маслов В.П. 1966. Некоторые кайнозойские харофиты юга СССР и методика их изучения // Ископаемые харофиты СССР. Москва: Наука. С. 10-200].

Maslov, V.P. 1963. Introduction into studying of fossil Charophyte algae. Geologicheskii Institut SSSR, Moscow, 104 pp. (in Russian). [Маслов В.П. Введение к изучению выкопных харовых водорослей. М.: ИзА-во АН ССР. 104 с.].

Mattox, K.R. \& K.D. Stewart 1984. Classification of gree algae: a concept based on comparative cytology. In: Systematics of the green algae, (D.E.G. Irvine \& D.M. John, eds.), pp. 29-72, Academic Press, London, Orlando.

McCourt R.M., K.G. Karol, M. Guerlysquine \& M. Feist 1996. Phylogeny of extant genera in the family Characeae (division Charophyta) based on $r b c \mathrm{~L}$ sequence and morphology. American Journal of Botany 83: 125-131.

McCourt, R.M., C.F. Delwiche \& K.G. Karol 2004. Charophyte algae and long plant origins. Trends in Ecology \& Evolution 19(12): 661-666.

McManus H.A. \& Y-L. Qiu 2008. Life cycles in major lineages of fotosynthetic eukaryotes, with a special reference to the origin of land plants. Fieldiana Botany 47: 17-33.

Melkonian, M., B. Marin \& B. Surek 1995. Phylogeny and evolution of the algae. In: Biodeversity and evolution, (Arai, R., M. Kato \& Y. Doi, eds.), pp. 153-176. The National Science Museum Foundation, Tokyo.

Mishler, B. D. \& S.P. Churchill 1985. Transition to land flora: phylogenetic relationships of the green algae and bryophytes. Cladistics 1:305-328.

Palamar-Mordvintseva, G.M. \& P.M. Tsarenko 2009. Place and significance of Charales in the organic world system. Al'gologia 11(4):305-3014 (in Russian). [Паламарь-МорАвинцева Г.М., Царенко П.М. Место и значение Charales в системе органического мира. Альгология. Т. 19, № 2. C. 117-134].

Palamar-Mordvintseva, G.M. 1980. Cytomorphological polymorphism and systematics of desmidial algae (Desmidiales). Ukrayins'kii Botanichnii Zhurnal 37(1):36-43 (in Ukrainian, with English summary). [Па^амар-Мордвинцева Г.М. 1980. Цитологічний поліморфізм і систематика десмідієвих водоростей (Desmidiales). Український ботанічний журнах Т. 37, №1. C. 36-43].

Palamar-Mordvintseva, G.M. 1982. Desmidian algae of the Ukrainian SSR. Naukova dumka, Kiev, 238 pp. (in Russian). ППаламар-Мордвинцева Г.М. 1982. Аесмидиевые водоросли Украинской ССР. Киев: Наукова Аумка. 238 с. ].

Palme, K., A. Dovzhenko \& F.A. Ditengou 2006. Auxin transport and gravitational research: perspective. Protoplasma 229:175-181.

Paponov, I.A., W.D. Teale, M. Trebar et al. 2005. The PIN auxin efflux facilitators: evolutionary and functional perspective. Trends in Plant Sciense 10:170-177.

Pickett-Heaps, J.D. \& H.J. Marchant 1972. The phylogeny of the green algae: a new proposal. Cytobious 6: 255-264.

Pickett-Heaps, J.D. 1967. Ultrastructure and differentiation in Chara sp. II. Mitosis. Australian journal of biological sciences 20:883-894.

Pickett-Heaps, J.D. 1975. Green algae. Structure, reproduction and evolution in selected genera. Sinauer Assoc., Stanford, 606 pp.

Pickett-Heaps, J.D., B.E.S. Gunning, R.C. Brown et al. 1999. The cytoplast concept in dividing plant cells: Cytoplasmic domains and the evolution of spatially organized cell division. American Journal of Botany 86:153-172.

Qiu, Y-L. 2008. Phylogeny and evolution of charophytic algae and land plants. Journal of Systematics and Evolution 
46(3):287-306.

Qiu, Y-L., J. Lee, F. Bernasconi-Quadroni et al. 2000. Phylogeny of basal anhiosperms: Analyses of five genes from three genomes. International Journal of Plant Sciences 161:S3-S27.

Qiu, Y-L., L.B. Li, B. Wang et al. 2007. A nonflovering land plant phylogeny inferred from nucleotide sequences of seven chloroplast, mitochondrial, and nuclear genes. International Journal of Plant Sciences 168:691-708.

Qiu, Y-L., Y.R. Cho, J.C. Cox \& J.D. Palmer 1998. The gain of three mitochondrial introns identifies livervorst as the earliest land plants. Nature 394:671-674.

Raven, J.A. \& D. Edwards 2001. Roots: evolutionary origins and biogeochemical significance. Journal of Experimental Botany 52:381-401.

Rodriguez-Ezpeleta, N., H. Phillipe, H. Brinkmann, B. Becker \& M. Melconian 2007. Phylogenetic analyses of nuclear, mitochondrial and plastid multigene data sets support the placement of Mesostigma in the Streptophyta. Molecular Biology and Evolution 24:723-731.

Ruhfel, B.R., M.A. Gitzendanner, P.S. Soltis, D.E. Soltis \& G. Burleigh 2014. From algae to angiosperms-infwrring the phylogeny of green plants (Viridiplantae) from 360 plastid genomes. BMC Environmental Biology 14:23.

Saidakovsky, L.Ya. \& I.M. Shaikin 1976. Stratigraphic importance of Charophyta in Ukraine. In: Tectonica and Stratigraphy. Issue 2., pp. 74-86, Naukova Dumka, Kiev (in Russian with Englich abstract). [СайАаковский $\Lambda . Я .$, Шайкин И.М. Стратиграфическое значение харофитов Украины // Тектоника и стратиграфия. Вып. 2. Киев: Наук. Аумка. С. 74-86].

Saidakovsky, L.Ya. 1993. Permian and Triassic Charophyta of the Earth. Al'gologia 3(2):76-82 (in Russian with English summary). [Сайлаковский $\Lambda . Я$. Пермские и триасовые Charophyta Земного шара // Альгология. Т. 3 , № 2. C. 76-82].

Shaikin, I.M., 1988. Evolution of Charophytes in Phanerozoic. Ukerayin'skii Botanichnii Zhurnal 45(6):79-84 (in Ukrainian, with English summary). Шайкін I.M. Еволюція харових водоростей в фанерозої / / Український ботанічний журнац. Т. 45, № 6. С. 79-84].

Taylor, E.L., N.T. Taylor \& M. Krings 2009. Paleobotany: The Biology and Evolution of Fossil Plants. 2 ed. Elsevier, London, New York, 1252 pp.

Timme, R.E., T.R. Bachvaroff \& Ch.F. Delwiche 2012. Broad phylogenomic sampling and the sister lineage of land plants. PLOS ONE 7(1):e29696(1-7).

Tompson, R.H. 1969. Sexual reproduction in Chaetosphaeridium globosum (Nordst) Klebahn (Chlorophyceae) and description of a new species to science. Journal of Phycology $5: 285-290$.
Turmel, M., C. Otis \& C. Lemieux 2005. The complete chloroplast DNA sequence of the charophycean green algae Staurastrum and Zygnema reveal that the chloroplast genome underwernt extensive changes during the evolution of the Zygnematales. BMC Biology 3:22(1-13).

Turmel, M., C. Otis \& C. Lemieux 2009. The chloroplast genomes of the green algae Pedinomonas minor, Parachlorella kessleri, and Oocystis solitaria reveal a shared ancestry between the Pedinomonadales and Chlorellales. Molecular Biology and Evolution 26:2317-2331.

Turmel, M., J.F. Pombert, P. Charlebois, C. Otis \& C. Lemieux 2007. The green algal ancestry of land plants as revealed by the chloroplast genome. International Journal of Plant Sciences 168:679-689.

Turmel, M., M. Ehara, C. Otis \& C. Lemieux 2002. Phylogenetic relationships among streptophytes as inferred from chloroplast small and large subunits rRNA gene sequences. Journal of Phycology 38:364-375.

Turmel, M., M.C. Gagnon, C.J. O’Kelly, C. Otis \& C. Lemieux 2009. The chloroplast genomes of the green algae Pyramimonas, Monomastix, and Pycnococcus shed new light on the evolutionary history of prasinophytes and the origin of the secondary chloroplasts of euglenids. Molecular Biology and Evolution 26:631-648.

Van den Hoek, C., D.G. Mann \& H.M. Jahns 1995. Algae: an introduction to phycology. Cambridge University Press, Cambridge, $700 \mathrm{pp}$.

Wille, N. 1912. Om udviklingen af Ulothrix flaccida Kütz. Svensk Botanisk Tidskrift 6:447-458.

Wodniok, S., H. Brinkmann, G. Glöckner, A.J. Heidel, H. Philippe et al. 2011. Origin of land plants: Do conjugating green algae hold the key? BMC Evolution Biology 11: 104.

Yehuda, G., S.S. Barinova, T. Krugman, T. Pavlicek, Y. Nov $\&$ E. Nevo 2013. Microscale adaptive response of charophytes of the Negev Desert, Israel: species divergences by AFLP. Natural Resources and Conservation 1(3):55-64.

Yoon, H.S., J.D. Hacket, C. Ciniglia, G. Pinto \& D. Bhattacharya 2004. A molecular timeline for the origin of fotosynthetic eucariotes. Molecular Biology and Evolution 21: 809-818.

Zhong, B., Zh. Xi, V.V. Goremykin, R. Fong, P.A. Mclenachan, Ph.M. Novis, Ch.C. Davis \& D. Penny 2013. Streptophyte algae and the origin of land plants revisited using heterogeneous models with three new algal chloroplast genomes. Molecular Biology and Evolution 31(1):177-183.

Zimmer, A., D. Lang, S. Richardt, W. Franck, R. Reski \& S.A. Rensing 2007. Dating the early evolution of plants: detection and molecular clock analyses of orthologs. Molecular Genetics and Genomics 278:393-402.

\section{Galina Palamar-Mordvintseva, Petro Tsarenko, Sophia Barinova:}

His numerous works, Valentin Abramovich is known botanist, evolutionist, paleontologist, paleoecologist, has had an undeniable influence on the formation of not only general evolution representations of the development of the organic world and terrestrial plants, in particular, but also on the outstanding issues (for a time) the theory of evolution. The role of algae in the development of terrestrial plants is generally recognized, and update and search for ancestral forms of this evolutionary line is still relevant. The charophytes are the key element in the issue of the origin and early evolution of flowering plants, the lighting of which Valentin Krassilov and presented in some of his monographs (Krassilov 1989, Krassilov, Rasnitsyn, 2008). His new, systemic approach to the evolution of the life helps us to reveal some properties of the charophytes diversity and distribution that cannot be seeing in the traditional approach. This article is an analysis of existing views on the process of evolution and phylogeny of the charophytes and their relationship to terrestrial plants in terms of addressing issues of contemporary evolution of plants dedicated to the memory of Valentin Abramovich. 